Running title: Detection of Salmonella using IMS-MDA real-time PCR

\title{
Rapid Detection of Salmonella in Raw Chicken Breast Using Real-time PCR Combined with Immunomagnetic Separation and Whole Genome Amplification
}

\author{
$\mathrm{Ji}^{-Y e o n}$ Hyeon $^{1}$, Xiangyu Deng ${ }^{1 *}$
}

Key words: Salmonella; detection; chicken; whole genome amplification; IMS; MDA; real-time PCR 


\begin{abstract}
We presented the first attempt to combine immunomagnetic separation (IMS), whole genome amplification by multiple displacement amplification (MDA) and real-time PCR for detecting a bacterial pathogen in a food sample. This method was effective in enabling real-time PCR detection of low levels of Salmonella enterica Serotype Enteritidis (SE) ( 10 CFU/g) in raw chicken breast without culture enrichment. In addition, it was able to detect refrigeration-stressed SE cells at lower concentrations $(\sim 0.1 \mathrm{CFU} / \mathrm{g})$ in raw chicken breast after a 4-h culture enrichment, shortening the detection process from days to hours and displaying no statistical difference in detection rate in comparison with a culture-based detection method. By substantially improving performance in SE detection over conventional real-time PCR, we demonstrated the potential of IMS-MDA real-time PCR as a rapid, sensitive and affordable method for detecting Salmonella in food.
\end{abstract}




\section{Introduction}

Nontyphoidal Salmonella enterica is one of the leading causes of foodborne illness worldwide, accounting for more than 1 million cases in the United States each year (Scallan et al., 2011). According to a report of the Foodborne Disease Outbreak Surveillance System by the Centers for Disease Control and Prevention, Salmonella was the second most common pathogen causing foodborne outbreaks and illnesses during 1998-2008 (Gould et al., 2013). One of the pathogencommodity pairs responsible for the majority of outbreaks was Salmonella and poultry (Gould et al., 2013), mainly due to the frequent contamination of poultry products by Salmonella. The Food Safety and Inspection Service estimated that the national prevalence of Salmonella in chicken parts is over 20\% (http://www.fsis.usda.gov/shared/PDF/

Baseline_Data_Raw_Chicken_Parts.pdf).

A number of rapid detection methods for Salmonella have been developed, particularly those built upon the technique of real-time PCR (Maurischat et al., 2015; Rodriguez-Lazaro et al., 2014; Wolffs et al., 2006; Zheng et al., 2016a). Due to the often low abundance and uneven distribution of Salmonella in food samples, real-time PCR-based detection of this pathogen is typically preceded by culture-based enrichment of Salmonella cells, which is often timeconsuming (e.g., overnight incubation) and constitutes a bottleneck to enabling same-day analysis without compromising detection sensitivity(Elizaquivel and Aznar, 2008; Ellingson et al., 2004; Liming and Bhagwat, 2004; Wolffs et al., 2006). 
Immunomagnetic separation (IMS) using magnetic beads coated with specific antibodies has been applied as an alternative to or in combination with culture-based enrichment for selective concentration of target pathogens and effective removal of PCR inhibitors from various food samples (Fedio et al., 2011; Foddai et al., 2010; Shields et al., 2012; Zheng et al., 2016b; 2014). IMS in combination with real-time PCR has been successfully used to isolate and detect Salmonella cells from food matrices of high fat and protein contents (Mercanoglu and Griffiths, 2005; Zheng et al., 2016a; Zheng et al., 2014). But in many cases, a culture enrichment step was still required to detect low levels of pathogens (Mercanoglu and Griffiths, 2005; Shields et al., 2012; Yang et al., 2007; Zheng et al., 2016b; 2014),

Besides bacterial cell division, which is intrinsically restricted in speed by the length of the cell cycle, whole genome amplification (WGA) of the target organism provides a rapid and sensitive sample preparation alternative for molecular detection of bacteria (Rodrigue et al., 2009). Multiple displacement amplification (MDA) is a widely used WGA technique that utilizes isothermal DNA amplification by highly efficient $\varphi 29$ polymerase (Hosono et al., 2003). Even with very low concentrations of starting materials, MDA can generate sufficient quantities of DNA for whole genome sequencing (WGS) of single (Rodrigue et al., 2009) or difficult-toculture bacterial cells (Seth-Smith et al., 2013a) and metagenomics detection of low-abundance species from complex environmental samples (Binga et al., 2008). The easiness, rapidity and acceptable cost of MDA make it an appealing method for real-time PCR sample preparation for foodborne pathogen detection.

In this study, we developed a sample processing approach for real-time PCR-based detection of Salmonella from raw chicken breast through the combination of targeted cell capture by IMS 
and highly efficient amplification of genomic DNA by MDA. The coupled workflow (IMS-MDA real-time PCR) allowed sensitive detection of Salmonella with shortened or no culture enrichment. We assessed the equivalence of IMS-MDA-real-time-PCR in detecting SE on raw chicken breast meat by comparing this method with real-time PCR after conventional DNA preparation and culture-based approach.

\section{Materials and Methods}

\subsection{Microorganism}

Overnight cultures of Salmonella enterica subsp. enterica serotype Enteritidis (SE) isolated from a poultry source were prepared by growing the stock culture in tryptic soy broth (TSB, Difco laboratory, Detroit, MI, USA) overnight at $37^{\circ} \mathrm{C}$ before use. Viable Salmonella counts were obtained by 10 -fold serial dilutions of overnight cultures in phosphate-buffered saline (PBS, pH 7.2, Amresco, Cleveland, OH, USA) and plating 100 microliters of the dilutions on tryptic soy agar (TSA, Difco laboratory). The plates were incubated at $37^{\circ} \mathrm{C}$ overnight and then single colonies were enumerated from the appropriate dilutions. To determine the limit of detection (LOD) of IMS-MDA real-time PCR and conventional real-time PCR in pure culture, 1 milliliter of 10-fold serial dilutions of pure cultures ranging from 10 to $10^{5} \mathrm{CFU} / \mathrm{ml}$ were used for IMS and DNA extraction.

\subsection{Chicken sample preparation}

Fresh, raw chicken breast meat was purchased from a grocery store in Athens, Georgia. Different sample weights were used in the study, $10 \mathrm{~g}$ to facilitate initial LOD estimation of IMS- 
MDA real-time PCR by concentrating the entirety of a smaller size homogenate $(90 \mathrm{ml}$ instead of $225 \mathrm{ml}$ from the $25 \mathrm{~g}$ sample) into bacterial pellet and $25 \mathrm{~g}$ to assess the equivalence of IMSMDA real-time PCR in comparison with conventional real-time PCR and culture method according to Microbiology Laboratory Guidebook of U.S. Department of Agriculture Food Safety and Inspection Service (USDA-FSIS). Each $10 \mathrm{~g}$ portion of raw chicken breast was aseptically placed into a sterile Whirl-pak filter bag (Nasco, Fort Atkinson, WI) and then inoculated with $1 \mathrm{ml}$ of SE inoculum $\left(10^{2}-10^{4} \mathrm{CFU} / \mathrm{ml}\right)$. For a negative control, un-inoculated chicken meat (10 g) was also prepared. All samples including the negative control were mixed with $90 \mathrm{ml}$ buffered peptone water (BPW, Difco Laboratory) followed by agitation in a laboratory stomacher blender (Seweard, Worthing, West Sussex, UK) for 30 seconds at medium speed. The $90 \mathrm{ml}$ homogenate of each sample was collected in a $50 \mathrm{ml}$ tube. For the comparison of different enrichment times, samples were incubated at $37^{\circ} \mathrm{C}$ for 2 or 4 hours before homogenate collection. The tubes were centrifuged at $100 \times \mathrm{g}$ for $10 \mathrm{~min}$ to remove solid debris in the homogenate. Each supernatant was carefully recovered and centrifuged at 3,000×g for 10 min to recover cell pellet. Each pellet was washed by re-suspension in $5 \mathrm{ml}$ of BPW followed by another round of centrifugation at 3,000×g for $10 \mathrm{~min}$. Finally, the pellet was re-suspended in 1 $\mathrm{ml}$ of BPW for unenriched samples and in $5 \mathrm{ml}$ of BPW for enriched samples.

A similar sample preparation method was used for the equivalence assessment of IMS-MDA real-time PCR by comparing it with conventional real-time PCR and culture-based detection as shown in Fig. 1. Specifically, for each inoculum size $(\sim 0.1,1$ and $10 \mathrm{CFU} / \mathrm{g}), 10$ samples $(25 \mathrm{~g}$ each) were included and the analysis was performed three times, resulting in a total of 90 tests for comparative assessment of the IMS-MDA real-time PCR method. In addition, a negative 
control (25 g un-inoculated chicken breast) and a positive control ( $25 \mathrm{~g}$ chicken breast inoculated with $10^{6} \mathrm{CFU} / \mathrm{ml}$ of SE) were also included in each trial. All inoculated chicken samples were stored at $4{ }^{\circ} \mathrm{C}$ overnight before testing to mimic actual raw meat storage and testing conditions. To accommodate the bigger sample weight, each chicken sample was placed in $225 \mathrm{ml} \mathrm{BPW}$ followed by hand massage for $30 \mathrm{~S}$. For IMS-MDA real-time PCR, $50 \mathrm{ml}$ homogenate were collected in centrifuge tubes before and after 4 hour enrichment and concentrated for IMS.

\subsection{IMS-MDA}

IMS with Dynabeads ${ }^{\circledR}$ anti-Salmonella $(2.5 \mu \mathrm{m}$ diameter) (Thermo Fisher Scientific, Waltham, MA, USA) was performed according to the manufacturer's instruction except increasing incubation time from $10 \mathrm{~min}$ to $30 \mathrm{~min}$ according to previous studies (Zheng et al., 2016b; Zheng et al., 2014). Briefly, $1 \mathrm{ml}$ of re-suspended cell pellet in BPW was incubated with $20 \mu \mathrm{l}$ of beads at room temperature using a rotating mixer (Thermo Fisher Scientific) for $30 \mathrm{~min}$. After incubation, the bead-Salmonella complexes were magnetically separated from the suspension using a magnetic particle concentrator (Thermo Fisher Scientific) for 3 min, and then washed three times with $1 \mathrm{ml}$ of PBS containing $0.05 \%$ (v/v) Tween 20 (Thermo Fisher Scientific) to remove non-specifically binding bacteria from the complex.

MDA was performed using Illustra GenomePhi V2 DNA amplification kit (GE Healthcare Life Sciences, Piscataway, NJ, USA) according to manufacturer's instruction. The bead-Salmonella complexes from IMS were re-suspended in $9 \mu$ of Sample buffer and incubated at $95{ }^{\circ} \mathrm{C}$ for 3 min for denaturation. After cooling to $4^{\circ} \mathrm{C}$ on ice, $9 \mu$ l of Reaction buffer with $1 \mu$ l of enzyme mix was combined to each sample on ice. After incubation at $30{ }^{\circ} \mathrm{C}$ for $1.5-2$ hours for 
amplification, the samples were heated to $65^{\circ} \mathrm{C}$ for $10 \mathrm{~min}$ to inactivate the enzyme and cooled to $4{ }^{\circ} \mathrm{C}$ on ice. Then, the final products (approximately $20 \mu \mathrm{l}$ ) were stored at $-20^{\circ} \mathrm{C}$ until use for real-time PCR.

\subsection{DNA preparation for conventional real-time PCR}

DNA templates for real-time PCR were extracted using PrepMan ${ }^{\mathrm{TM}}$ Ultra Reagent (Thermo Scientific). Briefly, $1 \mathrm{ml}$ of re-suspended cell pellet in BPW was centrifuged at $16,000 \times \mathrm{g}$ for 3 min, and the supernatant was aspirated and discarded. The cell pellet was re-suspended in $200 \mu \mathrm{l}$ PrepMan ${ }^{\mathrm{TM}}$ Ultra Reagent and then boiled for 10 min followed by cooling at room temperature for $2 \mathrm{~min}$. After centrifugation at $16,000 \times \mathrm{g}$ for $3 \mathrm{~min}$, the supernatant (approximately $200 \mu \mathrm{l}$ ) was collected in a new tube for use as DNA templates.

\subsection{Real-time PCR}

For real-time PCR reactions, the extracted DNA $(2 \mu \mathrm{l})$ or MDA product $(2 \mu \mathrm{l})$ was added into 18 $\mu l$ of PCR mixture. The mixture contained Taqman ${ }^{\circledR}$ Universal PCR Master Mix (10 $\mu$; Thermo Fisher Scientific), forward primer $(2 \mu \mathrm{l}, 900 \mathrm{nM})$, reverse primer $(2 \mu \mathrm{l}, 900 \mathrm{nM})$, probe $(2.5 \mu \mathrm{l}$, $250 \mathrm{nM})$, and distilled water $(2 \mu \mathrm{l})$. The sequences for the Salmonella-specific oligonucleotide primers and probe were designed to amplify a 94-bp segment of the ttr gene (GenBank accession no. AF 282268) (Malorny et al., 2004). An optimized real-time PCR protocol was used, specifying two holding periods, one at $50^{\circ} \mathrm{C}$ for $2 \mathrm{~min}$ and another at $95^{\circ} \mathrm{C}$ for $10 \mathrm{~min}$, followed by 40 cycles of $95^{\circ} \mathrm{C}$ for $15 \mathrm{~s}$ and $60^{\circ} \mathrm{C}$ for $60 \mathrm{~s}$. The threshold cycle $(\mathrm{Ct})$, which is the intersection between each fluorescence curve and a threshold line, was calculated using StepOne 
real-time PCR software version 2.0 (Thermo Fisher Scientific). Negative results correspond to Ct values $\geq 40$ or sample with $\mathrm{Ct}$ values higher than that of negative control. In addition, in order to rule out the presence of PCR inhibitor in the samples, internal amplification control (IAC) was tested using Taqman ${ }^{\circledR}$ Exogenous Internal Positive Control reagent (ThermoFisher Scientific).

\subsection{Culture-based detection}

For culture-based detection following Microbiology Laboratory Guidebook (USDA-FSIS), 0.1 and $1 \mathrm{ml}$ of 24-h pre-enriched homogenates in BPW were transferred to $10 \mathrm{ml}$ of RappaportVassiliadis soya (RVS) broth (Oxoid, Basingstroke, Hampshire, UK) and Muller-Kauffmann tetrathionate-novobiocin (MKTTn) broth (Oxoid), and incubated for $24 \mathrm{~h}$ at $42{ }^{\circ} \mathrm{C}$, respectively. After the selective enrichment, a loopful of each enriched sample was streaked on differential media: Xylose lysine Tergitol ${ }^{\mathrm{TM}} 4$ agar (XLT4, Oxoid) and Brilliant green sulfa agar (BGS; contains $0.1 \%$ sodium sulfapyridine, Oxoid). The presumptive Salmonella colonies from the selective agar were plated on TSA, followed by confirmation using real-time PCR.

\subsection{Statistical analysis}

The mean Ct values of each trial were analyzed to compare IMS-MDA real-time PCR and conventional real-time PCR. The statistical difference between the number of SE-positive samples of different detection methods was analyzed with GraphPad Software version 3.05 (San Diego, California, USA). The difference was considered to be statistically significant when $\mathrm{P} \leq$ 0.05. Fisher's exact probability tests for $2 \times 2$ contingency tables were applied to compare IMSMDA- real-time PCR, conventional real-time PCR, and culture method. To validate IMS-MDAreal-time PCR with 4-h enrichment, sensitivity, specificity, accuracy and Cohen's kappa index 
value were calculated by comparison with culture method (ISO:4833, 2003; ISO:16140, 2003;

Cohen, 1960).

\section{Results}

\subsection{LOD of conventional- and IMS-MDA real-time PCR in pure cultures and raw chicken breast}

In pure culture, IMS-MDA real-time PCR could detect SE at a minimum concentration of 10 $\mathrm{CFU} / \mathrm{ml}$, compared with that of $10^{2} \mathrm{CFU} / \mathrm{ml}$ by conventional real-time PCR (Figure. 2A). Similarly shown in Figure 2B, the LOD of conventional real-time PCR and IMS-MDA real-time PCR for detecting SE in raw chicken meat homogenate without incubation was $10^{3} \mathrm{CFU} / \mathrm{g}$ (with a $66.7 \%$ detection rate from 3 trials) and $10 \mathrm{CFU} / \mathrm{g}$ (with a $100 \%$ detection rate), respectively. The lower correlation coefficient between $\mathrm{Ct}$ values and SE concentrations from the IMS-MDA real-time PCR assay using pure cultures (Figure 2A) was likely due to the large quantities of DNA template amplified by MDA when higher than $10^{3} \mathrm{CFU} / \mathrm{ml} \mathrm{SE}$ cells were present, which led to the plateau of the standard curve.

\subsection{Comparison between IMS-MDA real-time PCR and conventional real-time PCR in} detecting Salmonella from chicken meat with and without culture enrichment

With an LOD of $\sim 10 \mathrm{CFU} / \mathrm{g}$ obtained by detecting $\mathrm{SE}$ in raw chicken breast samples using culture-independent IMS-MDA real-time PCR, we tried to further decrease the LOD by adding a short period ( 2 or 4 hours) of culture enrichment before IMS. As summarized in Table 1, after 2 
and 4-hour enrichment, this method allowed consistent detection of SE with the inoculum size being as low as about 0.1 and $1 \mathrm{CFU} / \mathrm{g}$, respectively. In comparison, real-time PCR with conventional sample preparation failed to detect SE in all experiment combinations unless the inoculum level reached about $10 \mathrm{CFU} / \mathrm{g}$ and culture enrichment lasted 4 hours $(66.7 \%$ detection rate).

\subsection{Equivalence assessment of IMS-MDA real-time PCR, real-time PCR following conventional DNA preparation, and culture method}

For this analysis, 4-hour culture enrichment was adopted as it appeared to be optimum for all the inoculum sizes previously tested. As shown in Table 1, a 4-hour culture enrichment led to improved detection compared with that of 1) no and 2-hour enrichment for conventional realtime PCR at 1 and $10 \mathrm{CFU} / \mathrm{g}$ inoculum levels, and 2) no enrichment for IMS-MDA real-time PCR at $0.1 \mathrm{CFU} / \mathrm{g}$ inoculum level. Compared with conventional DNA extraction, IMS-MDA led to improved performance in real-time PCR-based detection of SE by yielding significantly more positive results under all experiment conditions, except when no enrichment was performed and low inoculum size $(0.08 \pm 0.06 \mathrm{CFU} / \mathrm{g})$ was used (Table 2$)$. When preceded by a 4-hour culture enrichment, the detection rate of IMS-MDA real-time PCR appeared to be almost on par with that of culture-based detection at medium $(1.1 \pm 0.6 \mathrm{CFU} / \mathrm{g})$ or high $(11.8 \pm 5.4 \mathrm{CFU} / \mathrm{g})$ inoculum levels (Table 2) by detecting 27 and 29 out of 30 samples, respectively, and did not show significant difference from culture detection at the low inoculum size $(0.08 \pm 0.06 \mathrm{CFU} / \mathrm{g}, P>$

0.05) (Table 2). No false positive sample was detected by IMS-MDA real-time PCR at any of the 
inoculation levels (data not shown). In addition, IAC amplification was detected between 26 and 33 cycle numbers (data not shown).

To assess the equivalence of IMS-MDA real-time PCR with 4-hour enrichment in comparison with culture method, sensitivity, specificity, accuracy and Cohen's kappa index value were calculated (Table 3) (ISO:4833, 2003; ISO:16140, 2003; Cohen, 1960). Higher sensitivity and accuracy were observed as the inoculum levels were increased and specificity was $100 \%$ at any

of the inoculation levels (Table 3). In addition, Cohen's kappa index indicated clear concordance of IMS-MDA real-time PCR with 4-hour enrichment with culture method at the low inoculum level $(0.1 \mathrm{CFU} / \mathrm{g})$, strong concordance at the medium inoculation level (1 CFU/g), and nearly complete concordance at the high inoculation level (10 CFU/g) (Table 3) (ISO:4833, 2003; ISO: 16140, 2003; Cohen, 1960).

\section{Discussion}

Most rapid sample preparation methods for real-time PCR-based pathogen detection in food samples, including IMS, centrifugation, and filtration (D'urso et al., 2009; Fukushima et al., 2007; Notzon et al., 2006; Wolffs et al., 2006), have been intended for separation or concentration of pathogen cells. While such methods were effective to various degrees in certain food samples, it remains challenging for any of them alone to enable highly sensitive detection by real-time PCR. IMS, for example, can be subjected to non-specific binding of competitive flora (Mercanoglu and Griffiths, 2005) and interference from fat particulates or proteins in food (Fu et al., 2005; Zheng et al., 2014). Due to technical limitations of these methods, we complemented IMS with MDA, which indiscriminately amplified genomic DNA of various 
organisms bound to immunomagnetic beads including SE to facilitate its subsequent detection. This approach has been reported to allow culture-independent detection of Chlamydia trachomatis from clinical samples by high-throughput sequencing (Seth-Smith et al., 2013b). In this study, we applied a similar method to pathogen detection in a food sample with the more accessible real-time PCR technique.

Being able to detect SE from raw chicken meat at $100 \mathrm{CFU} / 10 \mathrm{~g}$ without enrichment and 1 CFU/10 g with a 4-h enrichment, the LOD of our approach was remarkably lower than that of IMS-real-time PCR assays of previous studies, which ranged from $2.5 \times 10^{4}$ to $10^{5} \mathrm{CFU} / 25 \mathrm{~g}$ for Salmonella detection in raw duck wing (Zheng et al., 2014), ground beef (Wang et al., 2007), and mung bean sprout (Zheng et al., 2016b). The 4-h enrichment time that helped to achieve consistent detection of SE at $\sim 10$ and $\sim 100 \mathrm{CFU} / 10 \mathrm{~g}$ in raw chicken meat was considerably shorter than that of previous reports with a comparable LOD, such as 6 hours in pork cutlet (Notzon et al., 2006), 7 hours in raw duck wing (Zheng et al., 2014), and 10 hours in ground beef (Mercanoglu and Griffiths, 2005).

Our equivalence assessment of the IMS-MDA real-time PCR assay was intended to imitate actual meat testing conditions by incorporating overnight storage of artificially contaminated meat samples under a refrigeration temperature. This procedure would have likely caused sublethal injury to SE cells, a typical physiological condition of pathogens in food (Lofstrom et al., 2011; Notzon et al., 2006). In addition, longer storage time might allow SE cells to better interact with meat and become less likely to be separated by washing and agitation. This may contribute to the lower detection probabilities observed in this study (Table 2) in comparison with that of previous assays (Table 1) to detect freshly inoculated SE. Moreover, the difference in sample 
weights (10 g vs. $25 \mathrm{~g}$ ), the amount of chicken meat homogenate $(90 \mathrm{ml}$ vs. $225 \mathrm{ml})$ and the numbers of samples ( 3 vs. 30) in the two studies may also partially explain the lower detection probabilities obtained in the equivalence assessment study.

It is also worth noting that the observed lower LOD of IMS-MDA real-time PCR compared with that of conventional real-time PCR indicates a difference in the concentration of target Salmonella DNA in the DNA samples prepared by the two different methods prior to real-time PCR. Multiple factors may contribute to such a difference including the different final volumes of the DNA samples (200 $\mu 1$ of conventional PCR vs $20 \mu 1$ of IMS-MDA real-time PCR) and the respective efficiency of specific MDA and DNA extraction kits. In the current study, we did not include an evaluation of how IMS or MDA alone may improve the SE detection by real-time PCR, the former of which has been previously reported (Notzon et al., 2006, Mercanoglu and Griffiths, 2005; Wang et al., 2007; Zheng et al., 2014; 2016b). Therefore, the net effect of MDA on SE detection by real-time PCR cannot be assessed and the observed improved detection was partly caused by IMS.

As a mature technique, IMS kits for common foodborne pathogens are widely available. Besides antibodies, other ligands such as DNA aptamer (Bruno et al., 2009) and phages (Sun et al., 2001) can be utilized in a similar fashion to provide rapid pre-concentration of pathogen cells for MDA and subsequent molecular detection and identification. The successful application of IMS-MDA real-time PCR in SE detection from raw chicken meat suggests that this technique may be used for other pathogens and food samples.

\section{Acknowledgements}


The authors would like to thank Dr. Mark Harrison and Gwen Hirsch of the University of Georgia for kindly providing the bacterial strain and other support to this study. This work was supported in part by the USDA National Institute of Food and Agriculture Hatch project 1006141.

\section{References}

Binga, E.K., Lasken, R.S.Neufeld, J.D., 2008. Something from (almost) nothing: the impact of multiple displacement amplification on microbial ecology. ISME J 2, 233-241.

Bruno, J.G., Phillips, T., Carrillo, M.P.Crowell, R., 2009. Plastic-adherent DNA aptamermagnetic bead and quantum dot sandwich assay for Campylobacter detection. J Fluoresc $19,427-435$.

Cohen, J., 1960. A Coefficient of Agreement for Nominal Scales. Educ Psychol Meas 20, 37-46.

D'Urso, O.F., Poltronieri, P., Marsigliante, S., Storelli, C., Hernandez, M.Rodriguez-Lazaro, D., 2009. A filtration-based real-time PCR method for the quantitative detection of viable 
Salmonella enterica and Listeria monocytogenes in food samples. Food Microbiol. 26, $311-316$.

Elizaquivel, P.Aznar, R., 2008. A multiplex RTi-PCR reaction for simultaneous detection of Escherichia coli O157:H7, Salmonella spp. and Staphylococcus aureus on fresh, minimally processed vegetables. Food Microbiol. 25, 705-713.

Ellingson, J.L., Anderson, J.L., Carlson, S.A.Sharma, V.K., 2004. Twelve hour real-time PCR technique for the sensitive and specific detection of Salmonella in raw and ready-to-eat meat products. Mol. Cell Probes 18, 51-57.

Fedio, W.M., Jinneman, K.C., Yoshitomi, K.J., Zapata, R., Wendakoon, C.N., Browning, P.Weagant, S.D., 2011. Detection of E. coli O157:H7 in raw ground beef by Pathatrix immunomagnetic-separation, real-time PCR and cultural methods. Int. J. Food Microbiol. $148,87-92$.

Foddai, A., Elliott, C.T.Grant, I.R., 2010. Maximizing capture efficiency and specificity of magnetic separation for Mycobacterium avium subsp. paratuberculosis cells. Appl. Environ. Microbiol. 76, 7550-7558.

Fu, Z., Rogelj, S.Kieft, T.L., 2005. Rapid detection of Escherichia coli O157:H7 by immunomagnetic separation and real-time PCR. Int. J. Food Microbiol. 99, 47-57.

Fukushima, H., Katsube, K., Hata, Y., Kishi, R.Fujiwara, S., 2007. Rapid separation and concentration of food-borne pathogens in food samples prior to quantification by viablecell counting and real-time PCR. Appl. Environ. Microbiol. 73, 92-100. 
Gould, L.H., Walsh, K.A., Vieira, A.R., Herman, K., Williams, I.T., Hall, A.J.Cole, D., 2013. Surveillance for foodborne disease outbreaks - United States, 1998-2008. MMWR Surveill Summ 62, 1-34.

Hosono, S., Faruqi, A.F., Dean, F.B., Du, Y., Sun, Z., Wu, X., Du, J., Kingsmore, S.F., Egholm, M.Lasken, R.S., 2003. Unbiased whole-genome amplification directly from clinical samples. Genome Res 13, 954-964.

International Organization for Standardization (ISO):4833, 2003.. Microbiology of Food and Animal Feeding Stuffs — Horizontal Method for the Enumeration of Microorganisms Colony-Count Technique at 30 degrees C.

International Organization for Standardization (ISO):16140, 2003. Microbiology of food and animal feeding stuffs — Protocol for the validation of alternative methods.

Liming, S.H.Bhagwat, A.A., 2004. Application of a molecular beacon-real-time PCR technology to detect Salmonella species contaminating fruits and vegetables. Int. J. Food Microbiol. $95,177-187$.

Lofstrom, C., Schelin, J., Norling, B., Vigre, H., Hoorfar, J.Radstrom, P., 2011. Cultureindependent quantification of Salmonella enterica in carcass gauze swabs by flotation prior to real-time PCR. Int. J. Food Microbiol. 145 Suppl 1, S103-109.

Malorny, B., Paccassoni, E., Fach, P., Bunge, C., Martin, A.Helmuth, R., 2004. Diagnostic realtime PCR for detection of Salmonella in food. Appl Environ Microbiol 70, 7046-7052.

Maurischat, S., Baumann, B., Martin, A.Malorny, B., 2015. Rapid detection and specific differentiation of Salmonella enterica subsp. enterica Enteritidis, Typhimurium and its 
monophasic variant 4,[5],12:i:- by real-time multiplex PCR. Int J Food Microbiol 193, 8-14.

Mercanoglu, B.Griffiths, M.W., 2005. Combination of immunomagnetic separation with realtime PCR for rapid detection of Salmonella in milk, ground beef, and alfalfa sprouts. $J$. Food Prot. 68, 557-561.

Notzon, A., Helmuth, R.Bauer, J., 2006. Evaluation of an immunomagnetic separation-real-time PCR assay for the rapid detection of Salmonella in meat. J. Food Prot. 69, 2896-2901.

Rodrigue, S., Malmstrom, R.R., Berlin, A.M., Birren, B.W., Henn, M.R.Chisholm, S.W., 2009. Whole genome amplification and de novo assembly of single bacterial cells. PLoS One 4, e6864.

Rodriguez-Lazaro, D., Gonzalez-Garcia, P., Delibato, E., De Medici, D., Garcia-Gimeno, R.M., Valero, A.Hernandez, M., 2014. Next day Salmonella spp. detection method based on real-time PCR for meat, dairy and vegetable food products. Int J Food Microbiol 184, 113-120.

Scallan, E., Hoekstra, R.M., Angulo, F.J., Tauxe, R.V., Widdowson, M.A., Roy, S.L., Jones, J.L.Griffin, P.M., 2011. Foodborne illness acquired in the United States--major pathogens. Emerg Infect Dis 17, 7-15.

Seth-Smith, H.M., Harris, S.R., Scott, P., Parmar, S., Marsh, P., Unemo, M., Clarke, I.N., Parkhill, J.Thomson, N.R., 2013a. Generating whole bacterial genome sequences of lowabundance species from complex samples with IMS-MDA. Nat Protoc 8, 2404-2412.

Seth-Smith, H.M., Harris, S.R., Skilton, R.J., Radebe, F.M., Golparian, D., Shipitsyna, E., Duy, P.T., Scott, P., Cutcliffe, L.T., O'Neill, C., Parmar, S., Pitt, R., Baker, S., Ison, C.A., 
Marsh, P., Jalal, H., Lewis, D.A., Unemo, M., Clarke, I.N., Parkhill, J.Thomson, N.R., 2013b. Whole-genome sequences of Chlamydia trachomatis directly from clinical samples without culture. Genome Res 23, 855-866.

Shields, M.J., Hahn, K.R., Janzen, T.W., Goji, N., Thomas, M.C., Kingombe, C.B., Paquet, C., Kell, A.J.Amoako, K.K., 2012. Immunomagnetic capture of Bacillus anthracis spores from food. J. Food Prot. 75, 1243-1248.

Sun, W., Brovko, L.Griffiths, M., 2001. Use of bioluminescent Salmonella for assessing the efficiency of constructed phage-based biosorbent. J Ind Microbiol Biotechnol 27, $126-128$.

U.S. Department of Agriculture-Food Safety Inspection Service (USDA-FSIS), Microbiology Laboratory Guidebook. http://www.fsis.usda.gov/wps/wcm/connect/700c05fe-06a2-492aa6e1-3357f7701f52/MLG-4.pdf?MOD=AJPERES (accessed 16.10.10).

Wang, L., Li, Y.Mustaphai, A., 2007. Rapid and simultaneous quantitation of Escherichia coli 0157:H7, Salmonella, and Shigella in ground beef by multiplex real-time PCR and immunomagnetic separation. J. Food Prot. 70, 1366-1372.

Wolffs, P.F., Glencross, K., Thibaudeau, R.Griffiths, M.W., 2006. Direct quantitation and detection of Salmonellae in biological samples without enrichment, using two-step filtration and real-time PCR. Appl. Environ. Microbiol. 72, 3896-3900.

Yang, H., Qu, L., Wimbrow, A.N., Jiang, X.Sun, Y., 2007. Rapid detection of Listeria monocytogenes by nanoparticle-based immunomagnetic separation and real-time PCR. Int. J. Food Microbiol. 118, 132-138. 
Zheng, Q., Miks-Krajnik, M., Yang, Y., Lee, S.M., Lee, S.C.Yuk, H.G., 2016a. Evaluation of real-time PCR coupled with immunomagnetic separation or centrifugation for the detection of healthy and sanitizer-injured Salmonella spp. on mung bean sprouts. Int $J$ Food Microbiol 222, 48-55.

Zheng, Q., Miks-Krajnik, M., Yang, Y., Lee, S.M., Lee, S.C.Yuk, H.G., 2016b. Evaluation of real-time PCR coupled with immunomagnetic separation or centrifugation for the detection of healthy and sanitizer-injured Salmonella spp. on mung bean sprouts. Int. J. Food Microbiol. 222, 48-55.

Zheng, Q., Miks-Krajnik, M., Yang, Y., Xu, W.Yuk, H.G., 2014. Real-time PCR method combined with immunomagnetic separation for detecting healthy and heat-injured Salmonella Typhimurium on raw duck wings. Int. J. Food Microbiol. 186, 6-13. 


\section{Figure legend}

Figure 1. Flow diagrams of equivalence assessment of IMS-MDA real-time PCR, conventional real-time PCR, and culture method for detecting Salmonella in artificially inoculated chicken meats in this study.

Figure 2. Standard curves of conventional real-time PCR and IMS-MDA real-time PCR with SE pure cultures (A) and SE inoculated on raw chicken breast (B). 
Table 1. Comparison between IMS-MDA real-time PCR and conventional real-time PCR in the detecting freshly inoculated SE on raw chicken breast (sample weight $=10 \mathrm{~g}$ ).

$\mathrm{Ct}$ values $\pm \mathrm{S} . \mathrm{D}$ (number of samples tested positive/total number of samples)

\begin{tabular}{|c|c|c|c|c|c|c|}
\hline Enrichment & \multicolumn{2}{|r|}{$0 \mathrm{~h}$} & \multicolumn{2}{|r|}{$2 \mathrm{~h}$} & \multicolumn{2}{|c|}{$4 \mathrm{~h}$} \\
\hline $\begin{array}{l}\text { SE inoculum } \\
(\text { Av. } \pm \text { S.D } \\
\text { CFU/g) }\end{array}$ & $\begin{array}{l}\text { Real- } \\
\text { time } \\
\text { PCR }\end{array}$ & $\begin{array}{c}\text { IMS-MDA } \\
\text { real-time PCR }\end{array}$ & $\begin{array}{l}\text { Real- } \\
\text { time } \\
\text { PCR }\end{array}$ & $\begin{array}{c}\text { IMS-MDA } \\
\text { real-time PCR }\end{array}$ & $\begin{array}{c}\text { Real-time } \\
\text { PCR }\end{array}$ & $\begin{array}{l}\text { IMS-MDA } \\
\text { real-time } \\
\text { PCR }\end{array}$ \\
\hline $13 \pm 7.2$ & N.D ${ }^{a}$ & $31.9 \pm 2.6(6 / 6)$ & N.D & $29.1 \pm 1.7(6 / 6)$ & $36.5 \pm 1.1(4 / 6)$ & $\begin{array}{c}28.3 \pm 2.0 \\
(6 / 6)\end{array}$ \\
\hline $1.3 \pm 0.7$ & N.D & $33.6 \pm 1.2(6 / 6)$ & N.D & $33.3 \pm 2.5(6 / 6)$ & N.D & $\begin{array}{c}32.8 \pm 1.6 \\
(6 / 6)\end{array}$ \\
\hline $0.13 \pm 0.07$ & N.D & N.D & N.D & $36.9 \pm 0.2(2 / 6)$ & N.D & $\begin{array}{c}35.4 \pm 3.6 \\
(6 / 6)\end{array}$ \\
\hline
\end{tabular}

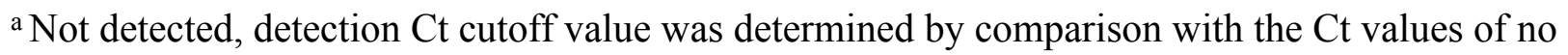
template controls and negative control samples.

Table 2. Comparison among IMS-MDA real-time PCR, conventional real-time PCR and culturing in detecting SE on raw chicken breast (sample weight $=25 \mathrm{~g}$ ) after overnight storage under refrigeration.

SE

Number of positive samples/number of tested samples 


\begin{tabular}{|c|c|c|c|c|c|c|}
\hline \multirow[b]{2}{*}{$\begin{array}{l}\text { inoculum } \\
(\text { Av. } \pm \text { S.D } \\
\text { CFU/g) }\end{array}$} & \multirow[b]{2}{*}{$\begin{array}{l}\text { Enrichment } \\
\text { time }\end{array}$} & & \multirow[b]{2}{*}{$P$ value $^{\mathrm{b}}$} & \multirow[b]{2}{*}{$\begin{array}{c}P \\
\text { value }^{\mathrm{c}}\end{array}$} \\
\hline & & $\begin{array}{c}\text { IMS-MDA } \\
\text { real-time } \\
\text { PCR }\end{array}$ & $\begin{array}{l}\text { Real-time } \\
\text { PCR }\end{array}$ & $\begin{array}{c}\text { Culture } \\
\text { method }^{\mathrm{a}} \\
(24 \mathrm{~h} \\
\text { enrichment) }\end{array}$ & & \\
\hline \multirow[t]{2}{*}{$11.8 \pm 5.4$} & $\begin{array}{l}\text { No- } \\
\text { enrichment }\end{array}$ & $18 / 30$ & $1 / 30$ & $30 / 30$ & $<0.001$ & 0.001 \\
\hline & $\begin{array}{c}4 \mathrm{~h} \\
\text { enrichment }\end{array}$ & $29 / 30$ & $8 / 30$ & & $<0.001$ & 1.0 \\
\hline \multirow[t]{2}{*}{$1.1 \pm 0.6$} & $\begin{array}{c}\text { No- } \\
\text { enrichment }\end{array}$ & $11 / 30$ & $2 / 30$ & $30 / 30$ & 0.0102 & $<0.001$ \\
\hline & $\begin{array}{c}4 \mathrm{~h} \\
\text { enrichment }\end{array}$ & $27 / 30$ & $5 / 30$ & & $<0.001$ & 0.2373 \\
\hline \multirow[t]{2}{*}{$0.08 \pm 0.06$} & $\begin{array}{c}\text { No- } \\
\text { enrichment }\end{array}$ & $2 / 30$ & $0 / 30$ & $24 / 30$ & 0.4915 & $<0.001$ \\
\hline & $\begin{array}{l}4 \mathrm{~h} \\
\text { enrichment }\end{array}$ & $17 / 30$ & $2 / 30$ & & $<0.001$ & 0.0946 \\
\hline
\end{tabular}

${ }^{\text {a }}$ Culture method was performed according to Microbiology Laboratory Guidebook (USDAFSIS) (24 h pre-enrichment)

${ }^{\mathrm{b}} P$ value $<0.05$ indicates a statistically significant difference between IMS-MDA real-time PCR and real-time PCR.

${ }^{\mathrm{c}} P$ value $<0.05$ indicates a statistically significant difference between IMS-MDA real-time PCR and culture method.

Table 3. Equivalence assessment of IMS-MDA real-time PCR with 4-h enrichment and culture method for the detection of SE on raw chicken breast after overnight storage under refrigeration. Negative controls (25 g un-inoculated chicken breast, $n=3)$ and positive controls ( $25 \mathrm{~g}$ chicken 
breast inoculated with $10^{6} \mathrm{CFU} / \mathrm{ml}$ of SE, $n=3$ ) were also included resulting in a total of 36 samples.

\begin{tabular}{|c|c|c|c|c|c|c|c|c|}
\hline \multirow{2}{*}{$\begin{array}{c}\text { SE } \\
\text { inoculum } \\
\text { (Av. } \pm \\
\text { S.D } \\
\text { CFU/g) }\end{array}$} & \multicolumn{2}{|c|}{$\begin{array}{l}\text { Culture } \\
\text { method }\end{array}$} & \multicolumn{2}{|c|}{$\begin{array}{l}\text { IMS-MDA real-time } \\
\text { PCR } \\
\text { (4 hour enrichment) }\end{array}$} & \multirow{2}{*}{$\begin{array}{l}\text { Sensitiv } \\
\text { ity } \\
(\%)\end{array}$} & \multirow{2}{*}{$\begin{array}{l}\text { Specifi } \\
\text { city } \\
(\%)\end{array}$} & \multirow{2}{*}{$\begin{array}{l}\text { Accur } \\
\text { acy } \\
(\%)\end{array}$} & \multirow{2}{*}{$\begin{array}{l}\text { Cohen's } \\
\text { kappa } \\
\text { index }{ }^{\mathrm{c}}\end{array}$} \\
\hline & $\begin{array}{c}\text { Positi } \\
\text { ve }\end{array}$ & $\begin{array}{c}\text { Negati } \\
\text { ve }\end{array}$ & $\begin{array}{c}\text { False } \\
\text { positive }^{\mathrm{a}}\end{array}$ & $\begin{array}{c}\text { False } \\
\text { negative }^{b}\end{array}$ & & & & \\
\hline $\begin{array}{c}11.8 \pm \\
5.4\end{array}$ & 33 & 3 & 0 & 1 & 97.0 & 100 & 97.2 & 0.84 \\
\hline $1.1 \pm 0.6$ & 33 & 3 & 0 & 3 & 90.9 & 100 & 91.7 & 0.63 \\
\hline $\begin{array}{c}0.08 \pm \\
0.06\end{array}$ & 27 & 9 & 0 & 7 & 74.1 & 100 & 80.1 & 0.59 \\
\hline
\end{tabular}

a Samples tested positive by IMS-MDA real-time PCR but negative by culture were regarded as false positive.

${ }^{\mathrm{b}}$ Samples tested negative by IMS-MDA real-time PCR but positive by culture were regarded as false negative.

'Cohen's Kappa index values of 0.41 and 0.60 indicate clear concordance, those between 0.61 and 0.80 indicated strong concordance, and those between 0.81 and 1.00 indicated nearly complete concordance. 


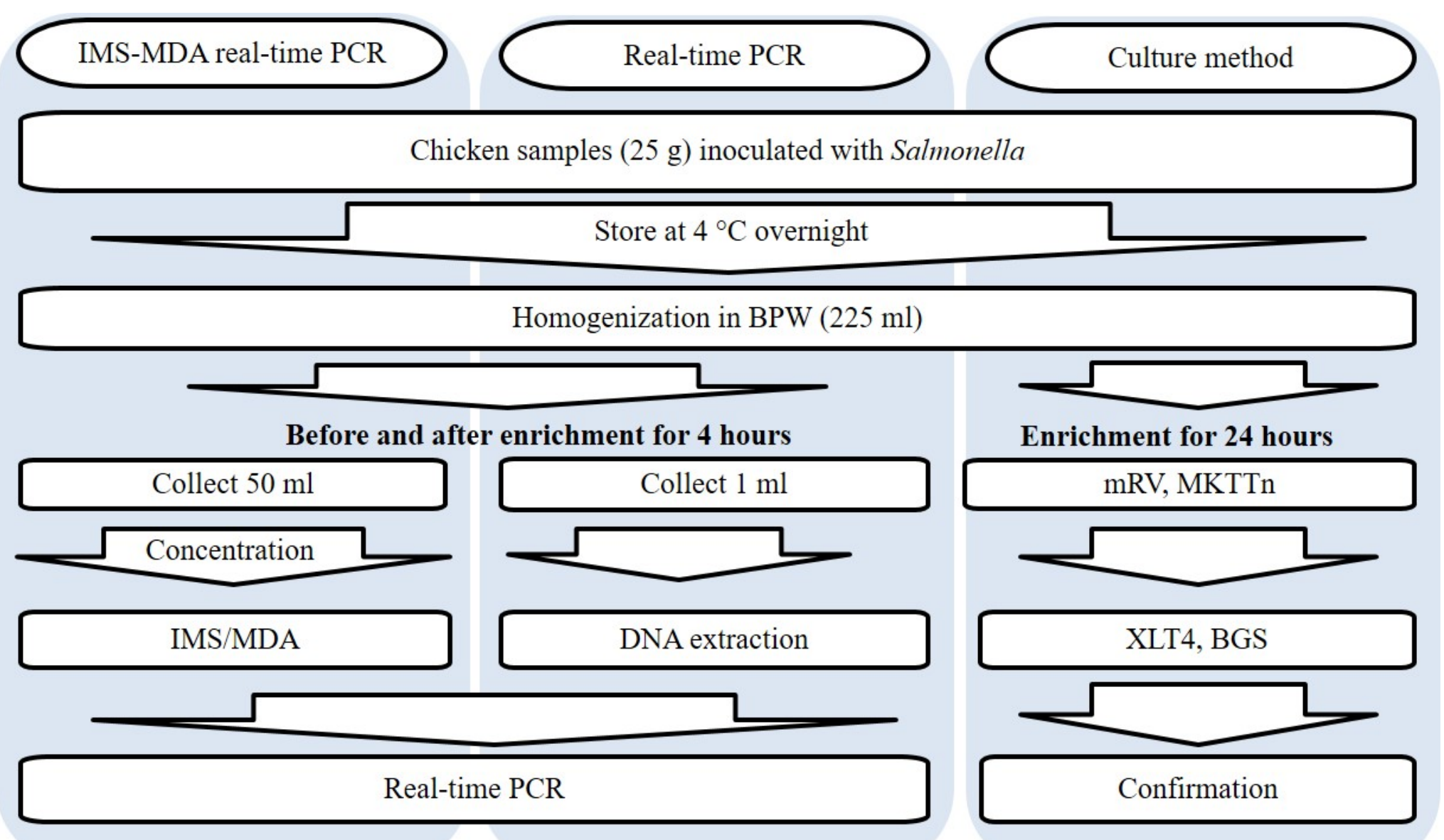


A

Ct value

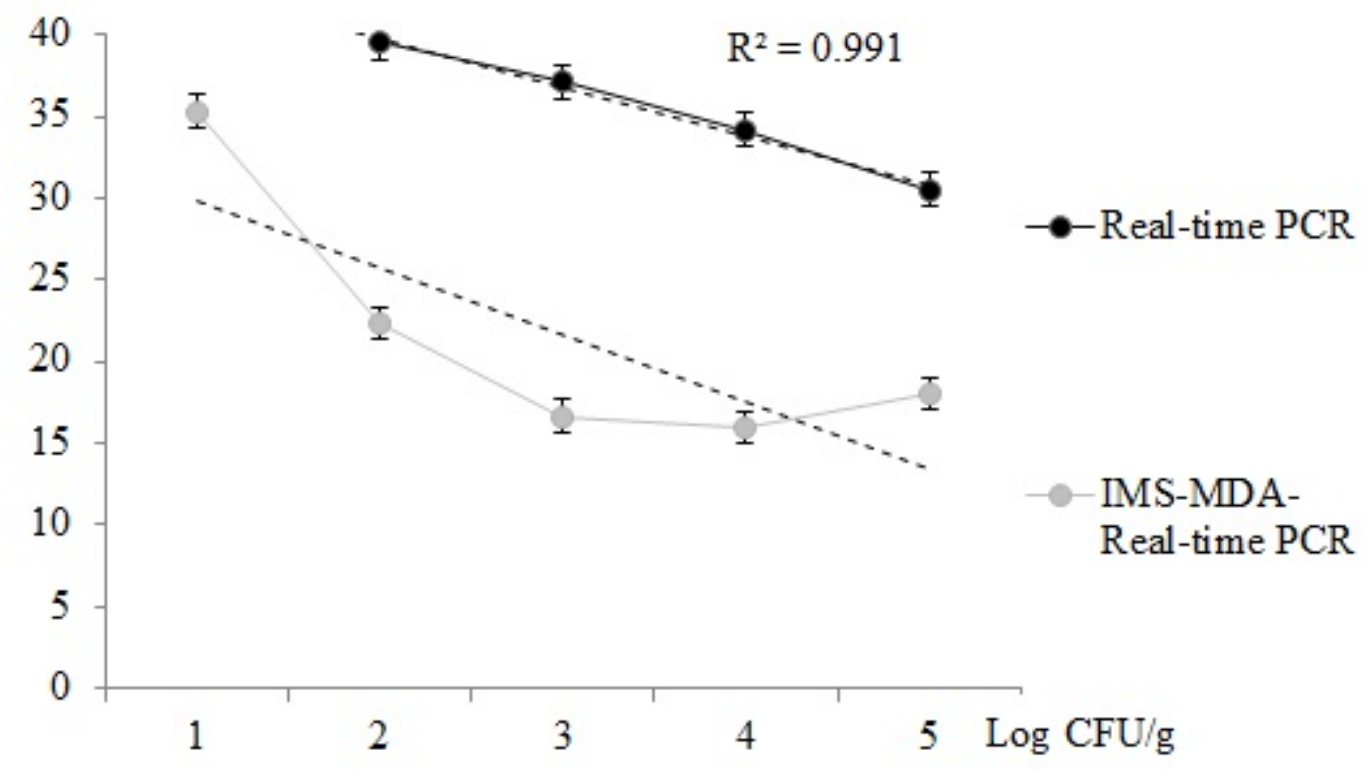

B

Ct value

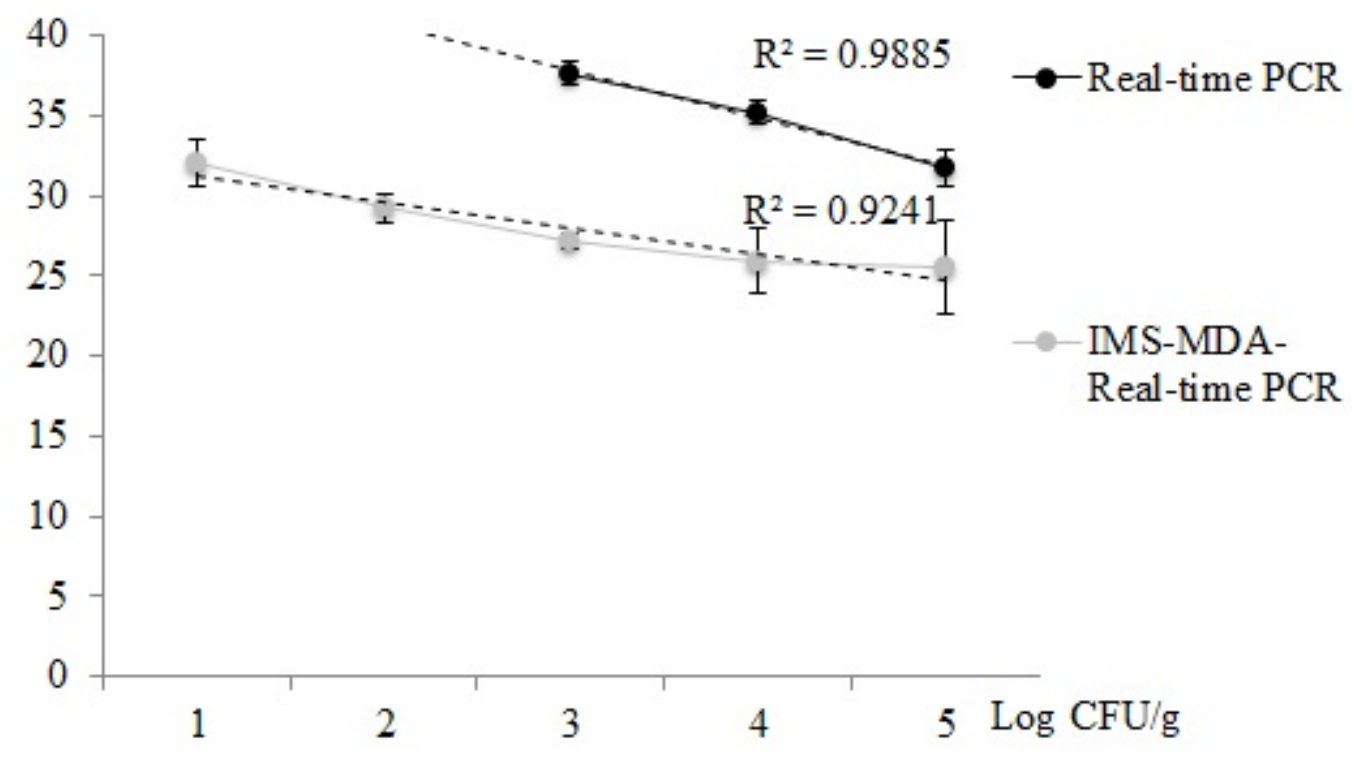

